\title{
Ameliorating effect of quercetin on epilepsy by inhibition of inflammation in glial cells
}

\author{
DONGMEI WU ${ }^{1,2^{*}}$, ZIHUI ZHENG $^{3^{*}}$, SHAOHUA FAN $^{1,2}$, XIN WEN $^{1,2}$, XINRUI HAN $^{1,2}$, \\ SHAN WANG ${ }^{1,2}$, YONGJIAN WANG ${ }^{1,2}$, ZIFENG ZHANG $^{1,2}$, QUN SHAN $^{1,2}$, \\ MENGQIU LI ${ }^{1,2}$, BIN HU ${ }^{1,2}$, YUANLIN ZHENG ${ }^{1,2}$ and JUN LU ${ }^{1,2}$
}

\author{
${ }^{1}$ Key Laboratory for Biotechnology on Medicinal Plants of Jiangsu Province, School of Life Science, \\ and ${ }^{2}$ College of Health Sciences, Jiangsu Normal University, Tongshan, Xuzhou, Jiangsu 221116; ${ }^{3}$ School of Medicine \\ and Holistic Integrative Medicine, Nanjing University of Chinese Medicine, Nanjing, Jiangsu 210023, P.R. China
}

Received July 06, 2019; Accepted March 10, 2020

DOI: $10.3892 /$ etm.2020.8742

\begin{abstract}
Epilepsy is a prevalent neurological disorder and it is a significant health risk, affecting $>50$ million people worldwide. The development of novel and appropriate strategies is required for ameliorating the progression and/or limiting the detrimental consequences of epilepsy. In the current study, kainic acid (KA), a neurotoxin, was used to induce seizures in mice. The flavonoid quercetin has recently been reported to have neuroprotective effects. Therefore, the effects of quercetin on KA-induced epilepsy and the potential underlying molecular mechanisms were examined. It was noted that quercetin attenuated the KA-induced seizure score and proinflammatory cytokine production, including tumor necrosis factor- $\alpha$ (TNF- $\alpha$ ) and interleukin- $1 \beta$ (IL-1 $\beta$ ), and activation of nuclear factor $\kappa B$ (NF-KB) in mice. Quercetin attenuated KA-induced proinflammatory cytokine (TNF- $\alpha$ and IL-1 $\beta$ ) release from microglia cells, as well as activation of NF-kB and ionized calcium binding adapter molecule 1 in microglia cells. Therefore, quercetin inhibited KA-induced epilepsy by microglia cell inactivation and the production of NF- $\mathrm{kB}, \mathrm{TNF}-\alpha$ and IL-1 $\beta$.
\end{abstract}

\section{Introduction}

Epilepsy is part of a group of neurological disorders characterized by a long-term risk of recurrent unprovoked seizures (1).

Correspondence to: Dr Jun Lu or Dr Yuanlin Zheng, Key Laboratory for Biotechnology on Medicinal Plants of Jiangsu Province, School of Life Science, College of Health Sciences, Jiangsu Normal University, 101 Shanghai Road, Tongshan, Xuzhou, Jiangsu 221116, P.R. China

E-mail: lu-jun75@163.com

E-mail: ylzheng@jsnu.edu.cn

*Contributed equally

Key words: quercetin, inflammation, epilepsy
According to statistics from a meta-analysis, $>65$ million people suffer from epilepsy worldwide (2). The majority of patients with epilepsy response well to anti-epileptic drugs, which control or reduce epileptic seizure occurrence. However, a number of patients gradually develop recurrent seizures and a resistance to anti-epileptic drugs (3). Further investigation is required to examine the underlying molecular mechanism of epilepsy and provide novel therapeutic approaches to fulfill clinical needs. Seizures are initiated by neuronal abnormality (4). Kainic acid (KA) is an agonist of kainite glutamate receptors and can induce their overstimulation, eventually leading to neuronal excitotoxicity and neuronal cell death (5). Therefore, KA is used in model systems to establish temporal lobe epilepsy, in order to study the mechanism and efficacy of drugs in epileptic seizures (6).

Inflammation processes have been clinically and experimentally reported to serve a pivotal role in the generation of seizures $(7,8)$. It was observed that inflammatory mediators are upregulated during the development of seizures in the mouse model (9). In patients with intractable epilepsy, the elevation of cytokines, including interleukin (IL)-1 $\beta$ was detected in the brain tissues (10). IL-1 $\beta$ blockers are therefore considered as a potential treatment approach for patients with epilepsy (11). Results from studies using KA model indicated that KA administration activated microglia and the release of several important cytokines, including tumor necrosis factor- $\alpha$ (TNF- $\alpha$ ), IL-1 $\beta$, IL-12 and IL-18 (12-15). IL-1 $\beta$ serves a key role in the recurrence of seizures by mediating enhanced calcium influx to induce proconvulsant effects (16).

Quercetin is derived from Quercetum (oaks) and is categorized as a flavonol (17). Previous studies suggested that quercetin shows anti-carcinogenic, anti-inflammatory, antiviral, antioxidant and psychostimulant activities $(17,18)$. For example, quercetin administration can decrease histological signs of acute inflammation in animals in a dose-dependent manner by inhibiting the release of chemokine and the lipid peroxidation end-product malondialdehyde, and increasing antioxidantenzyme activity (19). Quercetin also exhibits a neuro-protective function in several central nervous system disorders, including seizures and Huntington's disease $(20,21)$. Moghbelinejad et al (22) has 
suggested that quercetin regulated GABAA receptor $\alpha 5$, as well as $\beta 1$ and $\beta 3$, in a KA-induced seizure model of mice. However, the potential molecules regulated by quercetin in a KA-induced seizure remain to be investigated.

\section{Materials and methods}

Mouse model. A total of $30 \mathrm{male} \mathrm{BALB} / \mathrm{c}$ mice (weight 20-22 g; 8 weeks old) were purchased and housed in laboratory conditions (relative humidity of $45-55 \%, 12$-h-light/dark cycle, freely available food and water) at room temperature of $20-23^{\circ} \mathrm{C}$. Experiments were carried out in accordance with the International Guidelines for Animal Studies regarding the care and use of animals for experimental purposes (23). The study was approved by the Ethics Committee of School of Life Science at the Jiangsu Normal University. KA and quercetin were bought from Sigma-Aldrich (Merck KGaA).

$\mathrm{KA}$ and quercetin were dissolved in saline $(0.9 \% \mathrm{w} / \mathrm{v})$ and Tween-80 $(0.8 \% \mathrm{v} / \mathrm{v})$, respectively. The mice were divided into three groups consisting of 10 mice per group. The control group was intraperitoneally administered with saline $(10 \mu 1,0.9 \% \mathrm{w} / \mathrm{v}$, i.p.) + Tween-80 (10 $\mu 1,0.8 \% \mathrm{v} / \mathrm{v}$, i.p.) daily for one week and on the last day they were injected with saline $(10 \mu 1,0.9 \% \mathrm{w} / \mathrm{v}$, i.p.) + Tween-80 (10 $\mu 1,0.8 \% \mathrm{v} / \mathrm{v}$, i.p.) followed by saline $(10 \mu \mathrm{l}$, $0.9 \%$ w/v, i.p.) injection 30 min later. The mice in the KA group were injected daily with saline $(10 \mu 1,0.9 \%$ w/v,i.p. $)+$ Tween- 80 $(10 \mu 1,0.8 \% \mathrm{v} / \mathrm{v}$, i.p.) for one week and on the last day, the mice were injected with saline, and KA $(10 \mu 1,10 \mathrm{mg} / \mathrm{kg}$, i.p.) was subsequently intraperitoneally administered. In the $\mathrm{KA}+q u e r c e t i n$ group, the mice were intraperitoneally injected with quercetin $(10 \mu l, 100 \mathrm{mg} / \mathrm{kg}$, i.p. $)$ daily for one week and on the last day, $\mathrm{KA}(10 \mu 1,10 \mathrm{mg} / \mathrm{kg}$, i.p.) was administered $30 \mathrm{~min}$ following injection with quercetin $(10 \mu 1,100 \mathrm{mg} / \mathrm{kg}$, i.p.). Following injection of KA, mice were observed for behavioral changes over a period of $2 \mathrm{~h}$. In accordance with a previous study, the behavioral tests were scored from $0-6$ according to the following criteria: 0 , No response; 1 , immobility; 2 , rigid posture; 3 , scratching/circling/head bobbing; 4 , forelimb clonus/rearing/falling; 5 , repetitive pattern of 4 ; and 6 , severe tonic-clonic seizures (24). Following observation, mice were deeply anesthetized with sodium pentobarbital $(65 \mathrm{mg} / \mathrm{kg}$, intraperitoneally) and sacrificed using cervical dislocation. The hippocampus of each mouse was collected, cleaned with chilled saline at $4^{\circ} \mathrm{C}$ and frozen for subsequent experimentation.

Primary glial cell culture. Experiments were carried out in accordance with the International Guidelines for Animal Studies regarding the care and use of animals for experimental purposes (23). The study was approved by the Ethics Committee of School of Life Science at the Jiangsu Normal University. Glial cells were derived from 20 postnatal day 1-3 BALB/c mice purchased from the Branch of National Breeder Center of Rodents. Briefly, 5 neonatal mice were rinsed in $70 \%$ ethanol, followed by a quick decapitation. Afterwards, cerebral cortices were isolated, meninges were removed and tissue was minced and incubated with trypsin $(0.025 \%)$ for $15 \mathrm{~min}$ at $37^{\circ} \mathrm{C}$, followed with a trituration in the presence of DNAse I (50 $\mu \mathrm{g} / \mathrm{ml}$; Sigma-Aldrich; Merck KGaA) and $20 \%$ fetal bovine serum (FBS) in $\mathrm{Ca}^{2+}-\mathrm{Mg}^{2+}$-free PBS. Cells were suspended in DMEM (Gibco; Thermo Fisher Scientific, Inc.) supplemented

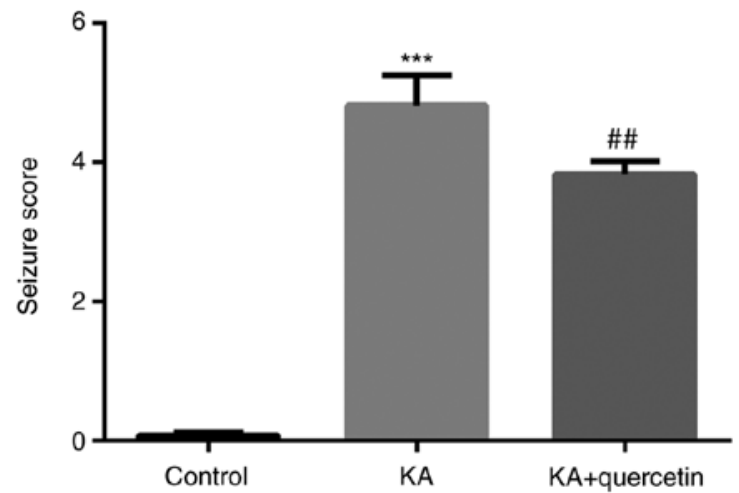

Figure 1. Effects of quercetin $(100 \mathrm{mg} / \mathrm{kg})$ on seizure score of mice with KA $(10 \mathrm{mg} / \mathrm{kg})$-induced seizures. ${ }^{* * *} \mathrm{P}<0.001 \mathrm{KA}$ group vs. control group, ${ }^{\# \#} \mathrm{P}<0.01 \mathrm{KA}+$ quercetin group vs. KA group. $\mathrm{n}=10$ mice in each group. KA, kainic acid.

with 10\% FBS (Gibco; Thermo Fisher Scientific, Inc.), 2 mM L-glutamine, $100 \mathrm{U} / \mathrm{ml}$ penicillin and $100 \mathrm{~g} / \mathrm{ml}$ streptomycin, thereafter, cells $\left(2 \times 10^{6}\right.$ cells/well $)$ were seeded onto poly-L-ornithine coated $6-\mathrm{cm}$ diameter Petri dishes and incubated in $95 \%$ humidity and $5 \% \mathrm{CO}_{2}$ at $37^{\circ} \mathrm{C}$. After incubation for 14 days, microglia were collected by shaking the mixed glial cell cultures for $1 \mathrm{~h}$. Thereafter, microglial cells $\left(5 \times 10^{4}\right.$ cells/well) were seeded into $96-w e l l$ plates and incubated in $95 \%$ humidity and $5 \% \mathrm{CO}_{2}$ at $37^{\circ} \mathrm{C}$ for $1 \mathrm{~h}$, followed by the removal of non-adhering cells by washing the plates. The final purity of microglia cells was $\sim 80 \%$.

Isolated microglia cells were then placed in DMEM followed by treatment with saline + Tween- 80 (control group) or KA alone (100 $\mu \mathrm{M}$; KA group) or $100 \mu \mathrm{M} \mathrm{KA}$ preceded by $10 \mathrm{nM}$ quercetin (KA+quercetin group). Treatment with quercetin was performed $30 \mathrm{~min}$ prior to KA treatment. Cells were treated with KA for $24 \mathrm{~h}$ then subjected to the following experiments.

Western blot analysis. TNF- $\alpha$ (cat. no. 11948; 1:1,000), IL-1 $\beta$ (cat. no. 31202; 1:1,000) and NF-кB p65 (cat. no. 8242; 1:2,000) and phospho-p65 (p-p65; cat. no. 3031; 1:1,000) antibodies were purchased from Cell Signaling Technology, Inc. Ionized calcium-binding adapter molecule 1 (IBA1; cat. no. ab178846; 1:2,000) and GAPDH (cat. no. ab181602; 1:10,000) antibodies were purchased from Abcam. HRP-conjugated secondary antibodies anti-rabbit (cat. no. ab7083; 1:10,000) and anti-goat (cat. no. ab7125; 1:10,000) were purchased from Abcam. Hippocampi were dissected and snap frozen in liquid $\mathrm{N}_{2}$ for subsequent protein extraction. Proteins from tissues and cells were isolated with RIPA lysis buffer (Sigma-Aldrich; Merck KGaA). The concentration of protein lysates was determined by a bicinchoninic acid kit (Sigma-Aldrich; Merck KGaA). Equal amount of proteins $(20 \mu \mathrm{g})$ were loaded and separated on an $8 \%$ SDS-PAGE gel. The proteins were transferred to a PVDF membrane, blocked by 5\% non-fat milk at room temperature for $2 \mathrm{~h}$ and washed by TBST (TBS contained $0.1 \%$ Tween-20) for 3 times (10 min/time). The membranes were then incubated with primary antibodies at $4^{\circ} \mathrm{C}$ overnight, washed by TBST for 3 times ( $\left.10 \mathrm{~min} / \mathrm{time}\right)$ and incubated with secondary antibodies at room temperature for $1 \mathrm{~h}$, washed by TBST for 3 times (10 min/time), successively. The blots were developed with ECL Western Blot kit (Pierce; 
A

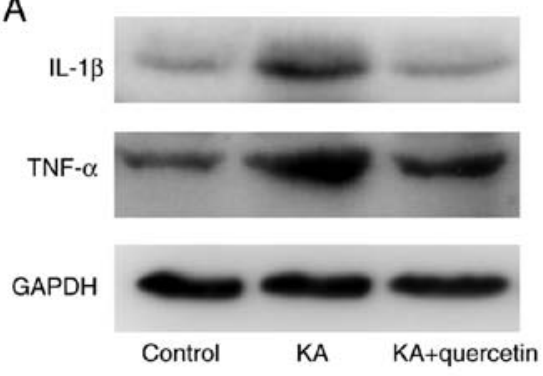

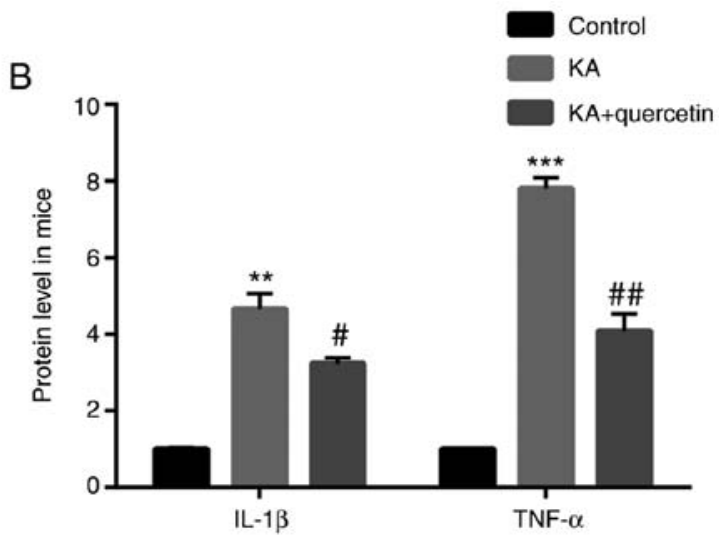

Figure 2. Effects of quercetin $(100 \mathrm{mg} / \mathrm{kg})$ on proinflammatory cytokine production in mice with $\mathrm{KA}(10 \mathrm{mg} / \mathrm{kg})$-induced seizures. (A) Western blotting and (B) quantification. ${ }^{* *} \mathrm{P}<0.01$ and ${ }^{* * *} \mathrm{P}<0.001 \mathrm{KA}$ group vs. control group, ${ }^{\#} \mathrm{P}<0.05$ and ${ }^{\# \#} \mathrm{P}<0.01 \mathrm{KA}+$ quercetin group vs. KA group. $\mathrm{n}=10$ mice in each group. KA, kainic acid; IL, interleukin; TNF, tumor necrosis factor.

A

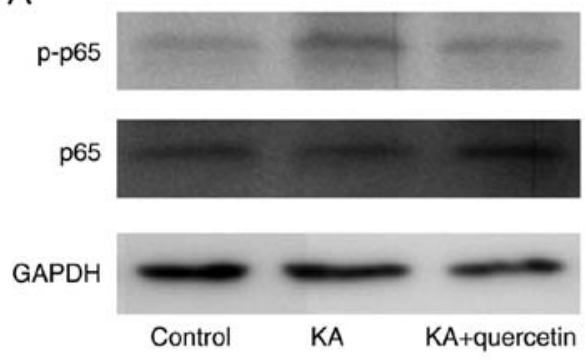

B

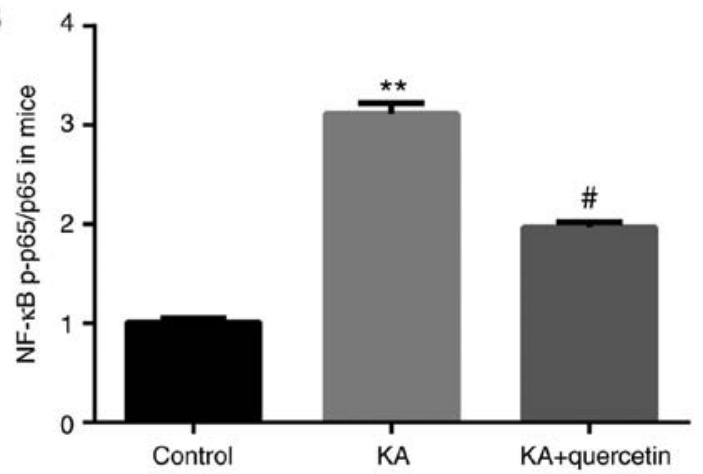

Figure 3. Effects of quercetin (100 mg/kg) on NF- $\mathrm{BB}$ production in mice with $\mathrm{KA}(10 \mathrm{mg} / \mathrm{kg}$ )-induced seizures). (A) Western blotting and (B) quantification. ${ }^{* *} \mathrm{P}<0.01 \mathrm{KA}$ group vs. control group, ${ }^{\#} \mathrm{P}<0.05 \mathrm{KA}+$ quercetin group vs. KA group. $\mathrm{n}=10$ mice in each group. KA, kainic acid; NF, nuclear factor; $\mathrm{p}$, phosphorylated.

Thermo Fisher Scientific, Inc.), according to the manufacturer's protocol. ImageJ software version 1.8.0 (National Institutes of Health) was used for densitometry analysis.

ELISA. The microglia cells were collected by scraping before the removal of the culture medium. Cells were washed with cold phosphate buffer saline (PBS), re-suspended in Tris- $\mathrm{Cl}$ (10 mM; pH 7.4) and lysed in triplicate. Protein content in the culture medium was then analyzed by ELISA using the Quantikine TNF- $\alpha$ (cat. no. MTA00B) and IL- $1 \beta$ (cat. no. MLB00C) ELISA kit (R\&D Systems, Inc.), according to the manufacturer's protocol.

Statistical analysis. The experiment was repeated three times and all data were calculated by GraphPad Prism 6.0 (GraphPad Software, Inc.) and presented as mean \pm standard deviation. Two groups were compared with unpaired Student's t-test. Three groups were firstly compared with one-way ANOVA followed by Newman Keuls analysis. $\mathrm{P}<0.05$ was considered to indicate a statistically significant difference.

\section{Results}

Quercetin attenuates $K A$-induced seizure score in mice. Compared with the control group, KA administration
(10 mg/kg) successfully caused seizures with a significantly increased seizure score $(\mathrm{P}<0.001,4.82 \pm 0.44$ vs. $0.08 \pm 0.04)$, which in turn was significantly reduced by quercetin administration $(100 \mathrm{mg} / \mathrm{kg})$ in the $\mathrm{KA}+$ quercetin group $(\mathrm{P}<0.01$, $3.83 \pm 0.18$ ) (Fig. 1). The results suggested the potential role of quercetin in relieving KA-induced epilepsy in mice.

Quercetin attenuates KA-induced proinflammatory cytokine production in mice. The results of the western blot analysis showed that mice in the KA group $(10 \mathrm{mg} / \mathrm{kg})$ exhibited increased TNF- $\alpha(\mathrm{P}<0.001)$ and IL-1 $\beta(\mathrm{P}<0.01)$ protein expression levels, when compared with those of the control group. In addition, TNF- $\alpha(\mathrm{P}<0.01)$ and IL-1 $\beta(\mathrm{P}<0.05)$ protein levels were lower in mice treated with quercetin $(100 \mathrm{mg} / \mathrm{kg})$ in the KA+quercetin group, when compared with those in the KA group (Fig. 2).

Quercetin attenuates $K A$-induced activation of $N F-\kappa B$ in mice. The results of the western blot analysis showed that there was increased NF- $\kappa \mathrm{B}$ phosphorylated (p)-p65 protein expression level in the KA group $(\mathrm{P}<0.01,10 \mathrm{mg} / \mathrm{kg})$, when compared with the control group, which was subsequently significantly decreased by quercetin treatment $(\mathrm{P}<0.05,100 \mathrm{mg} / \mathrm{kg})$. Meanwhile, there was no significant difference in NF- $\mathrm{B}$ p65 protein expression level between the 3 groups (Fig. 3). 

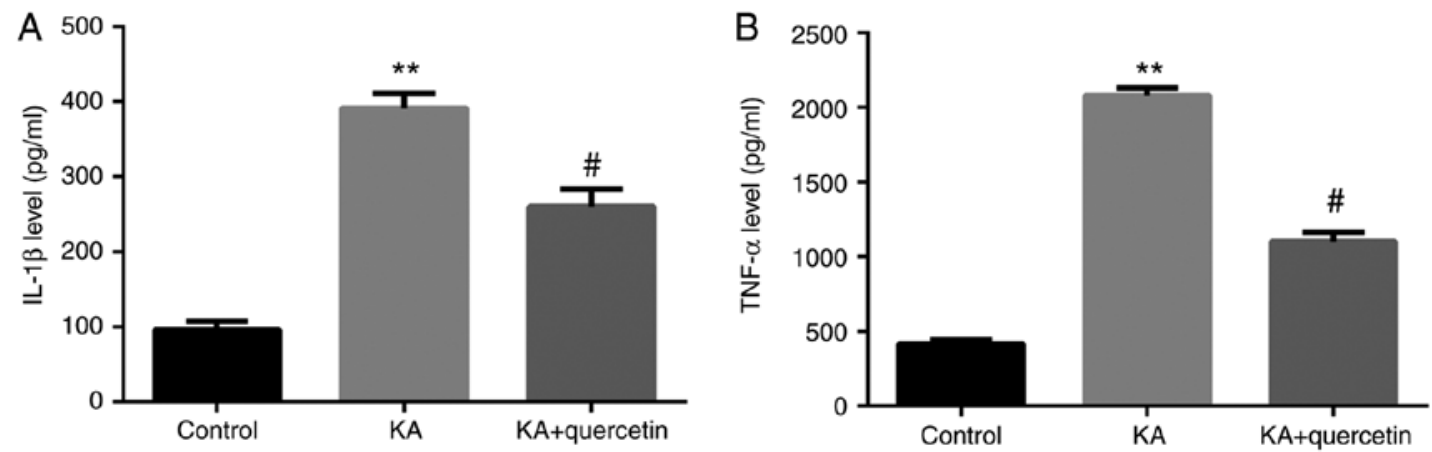

Figure 4. Effects of quercetin $(10 \mathrm{nM})$ on $\mathrm{KA}(100 \mu \mathrm{M})$-induced proinflammatory cytokine expression in microglia cells (A) IL-1 $\beta$ and (B) TNF- $\alpha{ }^{* *} \mathrm{P}<0.01$ KA group vs. control group, ${ }^{~} \mathrm{P}<0.05 \mathrm{KA}+$ quercetin group vs. KA group. $\mathrm{n}=6$, results are collected from different time of repeats. KA, kainic acid; IL, interleukin; TNF- $\alpha$, tumor necrosis factor- $\alpha$.

A

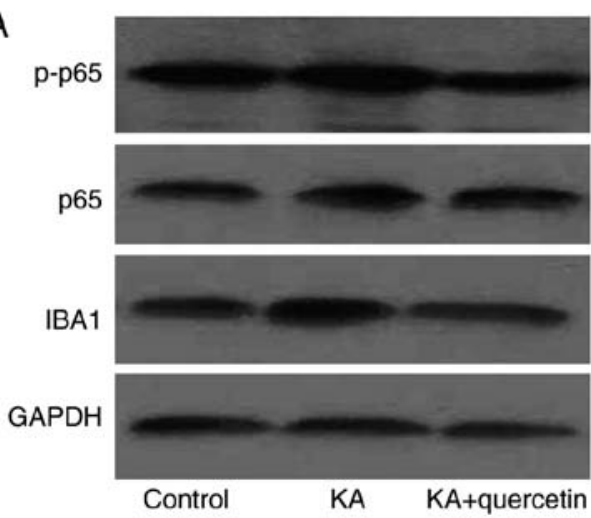

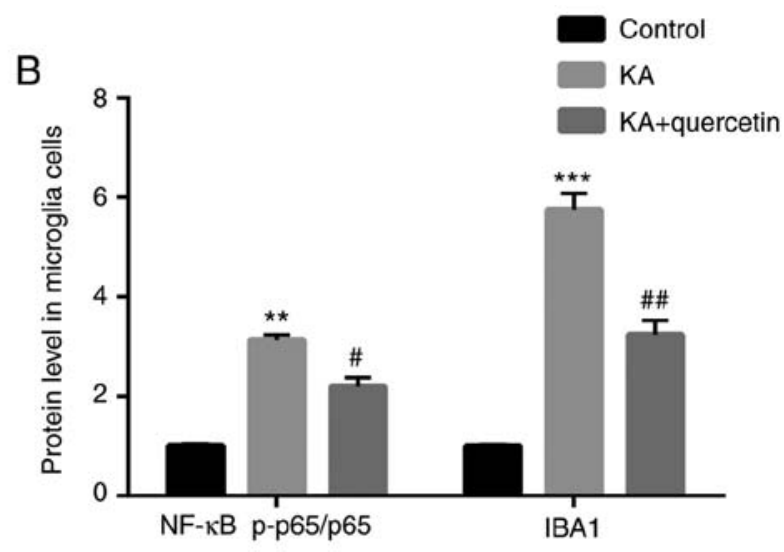

Figure 5. Effects of quercetin $(10 \mathrm{nM})$ on $\mathrm{KA}(100 \mu \mathrm{M})$-induced NF- $\mathrm{kB}$ activation and IBA1 in microglia cells. (A) Western blotting and (B) quantification. ${ }^{* *} \mathrm{P}<0.01$ and ${ }^{* * * *} \mathrm{P}<0.001 \mathrm{KA}$ group vs. control group, ${ }^{\#} \mathrm{P}<0.05$ and ${ }^{\# \#} \mathrm{P}<0.01 \mathrm{KA}+$ quercetin group vs. KA group. $\mathrm{n}=6$, results are collected from different time of repeats. KA, kainic acid; NF, nuclear factor; IBA1, ionized calcium-binding adapter molecule 1; p, phosphorylated.

Quercetin attenuates $K A$-induced proinflammatory cytokine release from microglia cells. Results from the ELISA demonstrated that the culture medium of $\mathrm{KA}(\mathrm{P}<0.01,100 \mu \mathrm{M})$-treated microglia cells expressed significantly increased protein levels of TNF- $\alpha$ and IL- $1 \beta$ compared with those of the non-treated group. Furthermore, in the culture medium of microglia cells, which were pre-treated with quercetin $(\mathrm{P}<0.05,10 \mathrm{nM})$ prior to KA, TNF- $\alpha$ and IL- $1 \beta$ expression levels were significantly decreased compared with those of the KA group (Fig. 4).

Quercetin attenuates $K A$-induced activation of $N F-\kappa B$ and microglia cells. The results of the western blot analysis showed that compared with the control group, NF- $\kappa \mathrm{B}$ p-p65 $(\mathrm{P}<0.01)$ expression levels were increased in the $\mathrm{KA}(100 \mu \mathrm{M})$ group, which were decreased by quercetin treatment $(\mathrm{P}<0.05,10 \mathrm{nM})$. There was no significant difference of NF- $\mathrm{B}$ p 65 protein expression level among the 3 groups (Fig. 5). In addition, compared with the control group, IBA1 $(\mathrm{P}<0.001)$ expression levels were higher in the KA $(100 \mu \mathrm{M})$ group, which were decreased by quercetin treatment $(\mathrm{P}<0.01,10 \mathrm{nM})$.

\section{Discussion}

The functions of quercetin in animal models of seizures have been studied and its anticonvulsant properties have been indicated in rats and mice (25-27). In addition, clinical and experimental evidence has been reported, which indicates the association between epilepsy and inflammation $(28,29)$. In addition, quercetin has been reported to serve anti-inflammatory roles by inhibiting the expression of pro-inflammatory cytokines, such as TNF- $\alpha$ and IL-1 $\beta$, in neurodegenerative diseases (30), including Parkinson's disease (31) and Alzheimer's disease (32). The aim of the present study was to investigate the potential therapeutic effects of quercetin and the underlying molecules that were regulated by quercetin in KA-induced epilepsy. The present study indicated that KA increased behavioral seizure activities and pro-inflammatory cytokines in the hippocampus of mice compared with the control group. However, quercetin decreased both of the aforementioned effects.

Neuroinflammation is characterized by the activation of microglia cells (33). Therefore, once activated, microglial cells take part in the inflammation process and facilitate the release of cytokines and chemokines, such as NF- $\kappa \mathrm{B}, \mathrm{TNF}-\alpha$ and IL-1 $\beta$ (34). Quercetin inhibits the production of nitric oxide in BV2 microglial cells via NF- $\mathrm{B}$ pathway inactivation (35). In addition, $\mathrm{KA}$ activates the $\mathrm{NF}-\kappa \mathrm{B}$ pathway prior to seizure occurrence (36).

Throughout the present study, in comparison with the control group, it was noted that KA increased TNF- $\alpha$, IL-1 $\beta$ 
and NF- $\mathrm{KB}$ expression levels in the hippocampus of mice, and these were subsequently decreased with quercetin treatment.

KA has been reported to activate microglia cells in epilepsy (37). The aforementioned experiments were also repeated in microglia cells in vitro, in order to examine whether quercetin attenuates KA-induced epilepsy by inhibiting the activation of microglia cells. It was indicated that compared with the control group, there were higher TNF- $\alpha$ and IL- $1 \beta$ expression levels in the culture medium of microglia cells in the KA group, which were subsequently diminished by quercetin. Meanwhile, compared with the control group, there were higher NF- $\kappa \mathrm{B}$ and IBA1 expression levels in microglia cells in the KA group, which were abolished by quercetin, indicating that it attenuates KA-induced epilepsy by inhibiting the activation of microglia cells.

In conclusion, the findings of the present study provide evidence on the role of quercetin in inhibiting KA-induced epilepsy by microglia cell inactivation and the production of NF- $\mathrm{BB}, \mathrm{TNF}-\alpha$ and IL-1 $\beta$. These findings highlight the potential role of quercetin in the treatment of epilepsy.

However, there are two limitations of the present study: One is the lack of analysis of different quercetin doses, the other is the lack of in vivo and pathology experiments, these will be the subject of future studies.

\section{Acknowledgements}

Not applicable.

\section{Funding}

This research was funded by the Priority Academic Program Development of Jiangsu Higher Education Institutions (PAPD); the 2013 'Qinglan Project' of the Young and Middle-aged Academic Leader of Jiangsu College and University, together with the 2016 '333 Project' Award of Jiangsu Province. The Cultivate National Science Fund for Distinguished Young Scholars of Jiangsu Normal University also offered grants. In addition, the present work also obtained supports by the Major Fundamental Research Program of the Natural Science Foundation of the Jiangsu Higher Education Institutions of China (grant no. 13KJA180001), together with the National Natural Science Foundation of China (grant no. 81571055, 81400902, 81271225, 81171012 and 30950031).

\section{Availability of data and materials}

The datasets used and/or analyzed during the current study are available from the corresponding author on reasonable request.

\section{Authors' contributions}

DW, JL, YZ designed the experiments. DW, ZZhe, SF, XW, $\mathrm{XH}, \mathrm{SW}$ collected samples and performed experiments. DW, ZZhe, YW, ZZha, QS, ML, BH collected and assembled data. DW, ZZhe, JL, YZ analyzed and interpreted the data. DW, ZZhe, SF, XW, XH, SW, YW, ZZha, QS, ML, BH were involved in drafting the manuscript and revising it critically for important intellectual content. All the authors read and approved the final manuscript.

\section{Ethics approval and consent to participate}

Experiments were carried out in accordance with the International Guidelines for Animal Studies regarding the care and use of animals for experimental purposes. The study was approved by the Ethics Committee of School of Life Science at the Jiangsu Normal University.

\section{Patient consent for publication}

Not applicable.

\section{Competing interests}

The authors declare that they have no competing interests.

\section{References}

1. Sankaraneni R and Lachhwani D: Antiepileptic drugs - a review. Pediatr Ann 44: e36-e42, 2015.

2. Ngugi AK, Bottomley C, Kleinschmidt I, Sander JW and Newton CR: Estimation of the burden of active and life-time epilepsy: A meta-analytic approach. Epilepsia 51: 883-890, 2010.

3. Kwan P, Arzimanoglou A, Berg AT, Brodie MJ, Allen Hauser W, Mathern G, Moshé SL, Perucca E, Wiebe S and French J: Definition of drug resistant epilepsy: Consensus proposal by the ad hoc Task Force of the ILAE Commission on Therapeutic Strategies. Epilepsia 51: 1069-1077, 2010.

4. Shapiro LA, Wang L and Ribak CE: Rapid astrocyte and microglial activation following pilocarpine-induced seizures in rats. Epilepsia 49 (Suppl 2): 33-41, 2008.

5. Zhang XM and Zhu J: Kainic acid-induced neurotoxicity: Targeting glial responses and glia-derived cytokines. Curr Neuropharmacol 9: 388-398, 2011 .

6. Reddy DS and Kuruba R: Experimental models of status epilepticus and neuronal injury for evaluation of therapeutic interventions. Int J Mol Sci 14: 18284-18318, 2013.

7. Friedman A and Dingledine R: Molecular cascades that mediate the influence of inflammation on epilepsy. Epilepsia 52 (Suppl 3): 33-39, 2011.

8. Pernot F, Heinrich C, Barbier L, Peinnequin A, Carpentier P, Dhote F, Baille V, Beaup C, Depaulis A and Dorandeu F: Inflammatory changes during epileptogenesis and spontaneous seizures in a mouse model of mesiotemporal lobe epilepsy. Epilepsia 52: 2315-2325, 2011.

9. Mazarati AM, Lewis ML and Pittman QJ: Neurobehavioral comorbidities of epilepsy: Role of inflammation. Epilepsia 58 (Suppl 3): 48-56, 2017.

10. Choi J, Nordli DR Jr, Alden TD, DiPatri A Jr, Laux L, Kelley K, Rosenow J, Schuele SU, Rajaram V and Koh S: Cellular injury and neuroinflammation in children with chronic intractable epilepsy. J Neuroinflammation 6: 38, 2009.

11. Vezzani A, Friedman A and Dingledine RJ: The role of inflammation in epileptogenesis. Neuropharmacology 69: 16-24, 2013.

12. Thompson C, Gary D, Mattson M, Mackenzie A and Robertson GS: Kainic acid-induced naip expression in the hippocampus is blocked in mice lacking TNF receptors. Brain Res Mol Brain Res 123: 126-131, 2004.

13. Eriksson C, Van Dam AM, Lucassen PJ, Bol JG, Winblad B and Schultzberg $\mathrm{M}$ : Immunohistochemical localization of interleukin-1beta, interleukin-1 receptor antagonist and interleukin-1beta converting enzyme/caspase- 1 in the rat brain after peripheral administration of kainic acid. Neuroscience 93: 915-930, 1999.

14. Chen Z, Duan RS, Concha QH, Wu Q, Mix E, Winblad B, Ljunggren HG and Zhu J: IL-12p35 deficiency alleviates kainic acid-induced hippocampal neurodegeneration in C57BL/6 mice. Neurobiol Dis 17: 171-178, 2004.

15. Jeon GS, Park SK, Park SW, Kim DW, Chung CK and Cho SS: Glial expression of interleukin-18 and its receptor after excitotoxic damage in the mouse hippocampus. Neurochem Res 33: $179-184,2008$.

16. Vezzani A, Aronica E, Mazarati A and Pittman QJ: Epilepsy and brain inflammation. Exp Neurol 244: 11-21, 2013. 
17. Li Y, Yao J, Han C, Yang J, Chaudhry MT, Wang S, Liu H and Yin Y: Quercetin, Inflammation and Immunity. Nutrients 8: 167, 2016.

18. Zheng J, Wu J, Chen J, Liu J, Lu Y, Huang C, Hu G, Wang X and Zeng Y: Therapeutic effects of quercetin on early inflammation in hypertriglyceridemia-related acute pancreatitis and its mechanism. Pancreatology 16: 200-210, 2016.

19. Dong YS, Wang JL, Feng DY, Qin HZ, Wen H, Yin ZM, Gao GD and Li C: Protective effect of quercetin against oxidative stress and brain edema in an experimental rat model of subarachnoid hemorrhage. Int J Med Sci 11: 282-290, 2014.

20. Nassiri-Asl M, Hajiali F, Taghiloo M, Abbasi E, Mohseni F and Yousefi F: Comparison between the effects of quercetin on seizure threshold in acute and chronic seizure models. Toxicol Ind Health 32: 936-944, 2016.

21. Chakraborty J, Singh R, Dutta D, Naskar A, Rajamma U and Mohanakumar KP: Quercetin improves behavioral deficiencies, restores astrocytes and microglia, and reduces serotonin metabolism in 3-nitropropionic acid-induced rat model of Huntington's Disease. CNS Neurosci Ther 20: 10-19, 2014.

22. Moghbelinejad S,Alizadeh S, Mohammadi G, Khodabandehloo F, Rashvand Z, Najafipour R and Nassiri-Asl M: The effects of quercetin on the gene expression of the GABAA receptor $\alpha 5$ subunit gene in a mouse model of kainic acid-induced seizure. J Physiol Sci 67: 339-343, 2017.

23. McGrath JC, Drummond GB, McLachlan EM, Kilkenny C and Wainwright CL: Guidelines for reporting experiments involving animals: The ARRIVE guidelines. Br J Pharmacol 160 $1573-1576,2010$

24. Morrison RS, Wenzel HJ, Kinoshita Y, Robbins CA, Donehower LA and Schwartzkroin PA: Loss of the p53 tumor suppressor gene protects neurons from kainate-induced cell death. J Neurosci 16: 1337-1345, 1996.

25. Nassiri-As1 M, Moghbelinejad S, Abbasi E, Yonesi F, Haghighi MR, Lotfizadeh $M$ and Bazahang P: Effects of quercetin on oxidative stress and memory retrieval in kindled rats. Epilepsy Behav 28: 151-155, 2013.

26. Nieoczym D, Socała K, Raszewski G and Wlaź P: Effect of quercetin and rutin in some acute seizure models in mice. Prog Neuropsychopharmacol Biol Psychiatry 54: 50-58, 2014.

27. Singh T, Kaur T and Goel RK: Adjuvant quercetin therapy for combined treatment of epilepsy and comorbid depression. Neurochem Int 104: 27-33, 2017.

28. Choi J and Koh S: Role of brain inflammation in epileptogenesis. Yonsei Med J 49: 1-18, 2008
29. Wheless JW, Clarke DF, Arzimanoglou A and Carpenter D: Treatment of pediatric epilepsy: European expert opinion, 2007. Epileptic Disord 9: 353-412, 2007.

30. Spagnuolo C, Moccia S and Russo GL: Anti-inflammatory effects of flavonoids in neurodegenerative disorders. Eur J Med Chem 153: 105-115, 2018.

31. Bournival J, Plouffe M, Renaud J, Provencher C and Martinoli MG: Quercetin and sesamin protect dopaminergic cells from $\mathrm{MPP}^{+}$-induced neuroinflammation in a microglial (N9)-neuronal (PC12) coculture system. Oxid Med Cell Longev 2012: 921941, 2012.

32. Moreno LCGEI, Puerta E, Suárez-Santiago JE, Santos-Magalhães NS, Ramirez MJ and Irache JM: Effect of the oral administration of nanoencapsulated quercetin on a mouse model of Alzheimer's disease. Int J Pharm 517: 50-57, 2017.

33. Chen WW, Zhang X and Huang WJ: Role of neuroinflammation in neurodegenerative diseases (Review). Mol Med Rep 13: 3391-3396, 2016

34. Rahimifard M, Maqbool F, Moeini-Nodeh S, Niaz K, Abdollahi M, Braidy N, Nabavi SM and Nabavi SF: Targeting the TLR4 signaling pathway by polyphenols: A novel therapeutic strategy for neuroinflammation. Ageing Res Rev 36: $11-19,2017$.

35. Kang CH, Choi YH, Moon SK, Kim WJ and Kim GY: Quercetin inhibits lipopolysaccharide-induced nitric oxide production in BV2 microglial cells by suppressing the NF- $\kappa$ B pathway and activating the Nrf2-dependent HO-1 pathway. Int Immunopharmacol 17: 808-813, 2013.

36. Miller JA, Kirkley KA, Padmanabhan R, Liang LP, Raol YH, Patel M, Bialecki RA and Tjalkens RB: Repeated exposure to low doses of kainic acid activates nuclear factor kappa $B$ $(\mathrm{NF}-\kappa \mathrm{B})$ prior to seizure in transgenic NF- $\mathrm{NB}$-EGFP reporter mice. Neurotoxicology 44: 39-47, 2014.

37. Bosco DB, Zheng J, Xu Z, Peng J, Eyo UB, Tang K, Yan C, Huang J, Feng L, Wu G, et al: RNAseq analysis of hippocampal microglia after kainic acid-induced seizures. Mol Brain 11: 34 , 2018.

This work is licensed under a Creative Commons Attribution-NonCommercial-NoDerivatives 4.0 International (CC BY-NC-ND 4.0) License. 